PREVENTIF: JURNAL KESEHATAN MASYARAKAT

FAKULTAS KESEHATAN MASYARAKAT, UNIVERSITAS TADULAKO

http://jurnal.fkm.untad.ac.id/index.php/preventif

\title{
Health Education About Hypertension Using Leaflet Media Effective On People's Knowledge And Attitudes Of The Community In Tanete Labba Hamlet, Maros
}

\author{
Yusma Indah Jayadi*', Widia Maharani ${ }^{1}$, Nurdiyanah ${ }^{1}$ \\ ${ }^{1}$ Public Health Departement, Faculty of Medicine and Health Science, \\ Alauddin State Islamic University Makassar, Indonesia \\ Author's Email Correspondence (*): yusmaindahji@gmail.com \\ (082348438373)
}

\begin{abstract}
Hypertension or high blood pressure is a serious medical condition that significantly increases the risk heart, brain, kidney, and other diseases. In COVID-19 patients, Arterial Hypertension (AH) is one of ti cardiovascular comorbidities that can worsen outcomes and increase the risk of admission to the intensi care unit (ICU). This study aims to measure the effectiveness of health education about hypertension ar blood pressure checks using the media leaflet on the knowledge and attitudes of the community in Tane Labba Hamlet, Maros.This research is a quasi-experimental research with Pre-test and Post-test witho Control Group Design in Tanete Labba Hamlet, Baji Pa'mai Village, Cenrana District, Maros Regency. Ti population in this study were residents of Tanete Labba Hamlet, Baji Pa'mai Village, using purposi sampling method with inclusion criteria of population aged 15 years and never or rarely had their heal checked so that a sample of 38 respondents was obtained. The analysis used is a paired T test. The purpo. of this counseling is to provide information related to hypertension risk factors, symptoms of hypertensio control and prevention of hypertension, namely in the form of recommendations to control blood pressu regularly at least every 6 months. Health education with leaflet media had a significant effect on the level knowledge $p=0.002(p<0.05)$ and the attitude of respondents $p=0.000(p<0.05)$ about hypertension ar blood pressure checks. Most of the community gave a positive response to the material presente enthusiastic in reading the contents of the leaflet and asking questions about hypertension and bloc pressure checks. It is important that education and counseling programs are developed according to ti needs of the community so that they can increase the knowledge of the general public and bring abo positive changes in attitudes and practices.
\end{abstract}

Keyword: Hypertension, Health Checkup, Health Counseling, Media Leaflet

Published by:

Tadulako University

Address:

Jl.Soekarno Hatta KM 9. Kota Palu, Sulawesi Tengah, Indonesia.

Phone: +628114120202

Email: Preventif.fkmuntad@gmail.com
Article history :

Received : 27112021

Received in revised form : 02122021

Accepted : 28122021

Available online 31122021

licensed by Creative Commons Attribution- 


\section{BACKGROUND}

Blood pressure is the force exerted by circulating blood against the walls of the body's arteries, the main blood vessels in the body. Hypertension is when blood pressure is too high. Hypertension is diagnosed if, when measured on two different days, the systolic blood pressure reading on both days is $140 \mathrm{mmHg}$ and/or the diastolic blood pressure reading on both days is $90 \mathrm{mmHg}$.(1).

Hypertension or high blood pressure is a serious medical condition that significantly increases the risk of heart, brain, kidney, and other diseases. There are 1.28 billion adults aged 30-79 years worldwide suffering from hypertension, most of them (two thirds) live in low and middle income countries. An estimated $46 \%$ of adults with hypertension are unaware that they have the condition. Less than half of adults (42\%) with hypertension are diagnosed and treated. About 1 in 5 adults (21\%) with hypertension can control it. Hypertension is the leading cause of premature death worldwide. One of the global targets for non-communicable diseases is to reduce the prevalence of hypertension by 33\% between 2010 and 2030(1).

The results of Riskesdas 2018 show the prevalence of hypertension in the population $>18$ years based on national measurements of $34.11 \%$, an increase compared to 2013 which was $25.8 \%$. This condition is very worrying. In South Sulawesi Province, the prevalence of hypertension based on the measurement results is $31.68 \%$, Maros Regency in particular $27.41 \%(2)$.

Hypertension can be prevented by checking blood pressure regularly. Blood pressure examination is one type of health examination or screening test that is carried out to anticipate the risk of hypertension. Health examination is a series of actions taken by examining the overall health of the body in order to detect various risks of disease(3).

In a study conducted in Italy, all patients underwent a complete clinical examination which included an ECG and 24-hour ambulatory blood pressure monitoring. At admission, the mean age of the patients was 50.0 years, $45 \%$ were women, and $6.1 \%$ had type 2 diabetes mellitus. The mean blood pressure in the office was $154 / 96 \mathrm{~mm} \mathrm{Hg}$, and the mean blood pressure was 154/96 mm $\mathrm{Hg}$. 24-hour outpatient treatment was 136/86 mm $\mathrm{Hg}$. The prevalence of left ventricular hypertrophy on ECG was $13.9 \%$. During follow-up, Sudden Cardiac Death (KJM) occurred in 33 patients at a rate of 0.10 per 100 patient-years $(95 \%$ CI, 0.07-0.14). KJM rates were 0.07 and 0.30 per 100 patient-years, respectively, in the cohort of patients without and with ECG left ventricular hypertrophy $(\mathrm{P}<0.01)$. In the multivariable Cox model with the Firth maximum refractive reduction method, left ventricular hypertrophy 
nearly tripled the risk of KJM (adjusted hazard ratio, 2.99; 95\% CI, 1.47-6.09; $\mathrm{P}=0.002$ ) after adjustment for age $(\mathrm{P}<0.0001)$, gender $(\mathrm{P}=0.019)$, diabetes mellitus $(\mathrm{P}<0.0001)$, and 24hour outpatient pulse pressure $(\mathrm{P}=0.036)$. For every $10 \mathrm{~mm} \mathrm{Hg}$ increase in 24-hour ambulatory pulse pressure, the risk of KJM increases by 35\%. The time dependent area under the receiver operating characteristic curve was 0.85 (95\% CI, 0.74-0.96). We conclude that in patients with hypertension without cardiovascular disease, age, diabetes mellitus, left ventricular hypertrophy ECG, and 24-hour ambulatory pulse pressure are independent prognostic markers for long-term KJM. 002) after adjustment for age $(\mathrm{P}<0.0001)$, gender $(\mathrm{P}=0.019)$, diabetes mellitus $(\mathrm{P}<0.0001)$, and 24-hour outpatient pulse pressure $(\mathrm{P}=0.036)$. For every $10 \mathrm{~mm} \mathrm{Hg}$ increase in 24-hour outpatient pulse pressure, the risk of KJM increases by $35 \%$. The time dependent area under the receiver operating characteristic curve was 0.85 (95\% CI, 0.74-0.96). We conclude that in patients with hypertension without cardiovascular disease, age, diabetes mellitus, left ventricular hypertrophy ECG, and 24-hour ambulatory pulse pressure are independent prognostic markers for long-term KJM. 002) after adjustment for age $(\mathrm{P}<0.0001)$, gender $(\mathrm{P}=0.019)$, diabetes mellitus $(\mathrm{P}<0.0001)$, and 24-hour outpatient pulse pressure $(\mathrm{P}=0.036)$. For every $10 \mathrm{~mm} \mathrm{Hg}$ increase in 24-hour ambulatory pulse pressure, the risk of $\mathrm{KJM}$ increases by $35 \%$. The time dependent area under the receiver operating characteristic curve was 0.85 (95\% CI, 0.74-0.96). We conclude that in patients with hypertension without cardiovascular disease, age, diabetes mellitus, left ventricular hypertrophy ECG, and 24-hour ambulatory pulse pressure are independent prognostic markers for long-term KJM. the risk of $\mathrm{KJM}$ increased by $35 \%$. The time dependent area under the receiver operating characteristic curve was 0.85 (95\% CI, 0.74-0.96). We conclude that in patients with hypertension without cardiovascular disease, age, diabetes mellitus, left ventricular hypertrophy ECG, and 24-hour ambulatory pulse pressure are independent prognostic markers for long-term KJM. the risk of $\mathrm{KJM}$ increased by $35 \%$. The time dependent area under the receiver operating characteristic curve was 0.85 (95\% CI, 0.74-0.96). We conclude that in patients with hypertension without cardiovascular disease, age, diabetes mellitus, left ventricular hypertrophy ECG, and 24-hour ambulatory pulse pressure are independent prognostic markers for long-term KJM.(4).

A study conducted by Roesmono, et al., in 2017 in Sidenreng-Rappang Regency, the results of research using the person chi-square test obtained a $\mathrm{p}$ value $=0.063$ with a significance level of $\mathrm{P}<0.05$, it can be concluded that there is a relationship between blood pressure control behavior and the incidence of hypertension. at Nene Mallomo Hospital, 
Sidenrappang Regency. The results of this study can be used as input for health institutions to provide motivation and understanding of the importance of controlling blood pressure for people with hypertension(5).

Another study on hypertension patients at the Massenga Health Center during 2017 was 742 people. The sampling technique was simple random sampling with a sample size of 117 people. Data were analyzed using chi-square test. The results showed that there was a relationship between education level $(\mathrm{p}=0.004)$, knowledge $(\mathrm{p}=0.000)$, access to health services $(\mathrm{p}=0.000)$ and family support $(\mathrm{p}=0.000)$ with routine blood pressure checks while the type of work variable was not associated with routine examination of blood pressure in hypertensive patients $(\mathrm{p}=0.386)(6)$.

The study was conducted by collecting data on individual participants from 4 randomized clinical trials of self-controlled blood pressure (SBMP) in the UK (combined $\mathrm{n}=$ 2590) with varying intensities of support. In conclusion, a combined analysis of individual participant data found that supported SMBP increased the likelihood of intensification of antihypertensive drugs over 12 months. Over 5 years, studies project that supported SMBP will significantly improve blood pressure control compared to usual care. Study results underscore the importance of SMBP as a viable way to improve long-term blood pressure outcomes(7).

Based on the health profile of the Cenrana District in 2019 it shows that hypertension occupies the third position of the highest disease, while in Tanete Labba Hamlet it is known that out of 155 respondents, there are 14 respondents (17.9\%) whose blood pressure examination results show high blood pressure and there are 8 respondents. (10.3\%) who had been diagnosed with hypertension by a doctor. Then, only 9 respondents $(5.8 \%)$ regularly checked their blood pressure and 69 respondents (44.5\%) occasionally checked their blood pressure. Based on this, the authors feel the need to conduct counseling related to hypertension and counseling on the importance of health checks, especially in the midst of the COVID-19 pandemic as an initial step in detecting the risk of Non-Communicable Diseases (NCDs).

\section{METHOD}

This research is a quasi-experimental research with Pre-test and Post-test without Control Group Design. This design does not use a control group but only uses one experimental group to be given treatment. Testing the effect of treatment on the measured 
variables is done by comparing the state of the variables before and after the treatment is given.

This experiment was carried out in three stages, namely first by giving a pre-test to measure the knowledge and attitudes of respondents before receiving treatment. Furthermore, providing treatment, namely providing health education using leaflet media regarding the importance of health checks. The last stage is to do a post-test by giving the same questionnaire as the pre-test to see the increase in the knowledge and attitudes of respondents after the treatment is given.

Interventions carried out using leaflets as a medium for delivering informationinformation related to hypertension risk factors, symptoms of hypertension, control and prevention of hypertension, as well as recommendations for regular health checks at least every 6 months. The types of health checks that are recommended include checking blood pressure, checking cholesterol, checking blood sugar, checking height and weight.

This research was conducted in Tanete Labba Hamlet, Baji Pa'mai Village, Cenrana District, Maros Regency. The population in this study were residents of Tanete Labba Hamlet, Baji Pa'mai Village. This study used a purposive sampling method with the inclusion criteria of population aged 15 years who suffered from hypertension or the results of blood pressure examinations had been above $140 / 90 \mathrm{mmHg}$, never or rarely had their health checked so that a sample of 38 respondents was obtained. The independent variable in this study is health education using leaflet media, while the dependent variable in this study is the knowledge and attitudes of respondents regarding the importance of health checks.

The research data was collected using a questionnaire instrument or a questionnaire which was composed of a set of list of questions and was closed, this was done to avoid widespread information because each respondent had a different base of knowledge and experience. Knowledge questions use the Guttman scale, which is a scale that uses two answer criteria (Yes and No) with the highest score of one and the lowest score of zero. The Guttman scale aims so that each respondent is able to provide a firm and consistent answer to the problem being asked(8). The researcher assigns a score for each positive question, i.e. yes, a score of 1 (one) and no, a score of 0 (zero), while for each negative question a score of 1 (one) is given for the answer no and a score of 0 (zero) for the answer yes. Knowledge is categorized as good if the respondent scores more than or equal to $50 \%$, while it is categorized as poor if the respondent scores less than $50 \%$. 
The attitude variable uses a Likert scale consisting of four choices of statements with varying scores, namely SS (Strongly Agree) $=1, \mathrm{~S}$ (Agree) $=2$, TS $($ Disagree $)=3$, and STS $($ Strongly Disagree $)=4$. There are 10 questions related to attitude, so it is categorized as positive if the respondent's answer score is more than or equal to $62.5 \%$ and is categorized as negative if the score is less than $62.5 \%$. Next, a paired sample t-test was analyzed to see the effect of health education on the variables of knowledge and attitudes of respondents related to the importance of health check-ups.

\section{RESULTS}

Table 1

Distribution of Respondents by Age and Gender on the Importance of Health Check-up in Dusun Tanete Labba, Baji Pa'mai Village, Cenrana District, Maros Regency 2020

\begin{tabular}{lccc}
\hline \multirow{2}{*}{ Variable } & & \multicolumn{2}{c}{ Total } \\
\cline { 3 - 4 } Age & $20-39$ & $\mathbf{N}$ & $\boldsymbol{\%}$ \\
& $40-59$ & 21 & 18.4 \\
& $>59$ & 10 & 55.3 \\
Gender & Man & 4 & 26.3 \\
& Woman & 34 & 10.4 \\
Total & & $\mathbf{3 8}$ & 89.6 \\
\hline
\end{tabular}

Source: Primary Data 2020

Based on table 1, most respondents are in the age category 40-59 years, as many as 21 respondents (55.3\%), and the majority are female, as many as 34 respondents (89.6\%), and as many as 4 respondents $(10.4 \%)$ are male. man.

Table 2

Distribution of Respondents' Knowledge Levels and Attitudes based on Pre-test and Post-test Responses Extension of the Importance of Health Checking with Leaflet Media in Tanete Labba Hamlet, Baji Pa'mai Village, Cenrana District, Maros Regency in 2020

\begin{tabular}{|c|c|c|c|c|c|}
\hline \multirow{2}{*}{ Variable } & \multirow{2}{*}{ Category } & \multicolumn{2}{|c|}{ Pre-Test } & \multicolumn{2}{|c|}{ Post-Test } \\
\hline & & $\mathbf{n}$ & $\%$ & $\mathbf{n}$ & $\%$ \\
\hline Knowledge & Well & 12 & 31.6 & 21 & 55.3 \\
\hline Attitude & $\begin{array}{l}\text { Not enough } \\
\text { Positive } \\
\text { Negative }\end{array}$ & $\begin{array}{l}26 \\
16 \\
22 \\
\end{array}$ & $\begin{array}{l}68.4 \\
42.1 \\
57.9 \\
\end{array}$ & $\begin{array}{l}17 \\
20 \\
18 \\
\end{array}$ & $\begin{array}{l}44.7 \\
52.6 \\
47.4 \\
\end{array}$ \\
\hline
\end{tabular}

Source: Primary Data 2020 
Based on table 2, it is known that before the intervention, as many as 12 respondents $(31.6 \%)$ had good knowledge regarding the importance of health check-ups and after the intervention increased to 21 respondents (55.3\%). Respondents' attitudes regarding the importance of health checks showed that before the intervention, 16 respondents $(42.1 \%)$ had a positive attitude regarding the importance of health checks and after the intervention increased to 20 respondents $(52.6 \%)$.

\section{Table 3}

The Effect of Health Education with Leaflet Media on the Knowledge Level and Attitude of Respondents regarding the Importance of Health Checking

\begin{tabular}{lccc}
\hline \multicolumn{1}{c}{ Variable } & $\begin{array}{c}\text { Pre-test } \\
(\text { Mean } \pm \text { SD) }\end{array}$ & $\begin{array}{c}\text { Post-test } \\
(\text { Mean } \pm \text { SD) }\end{array}$ & p \\
\hline Knowledge & $4.08 \pm 1.699$ & $5.82 \pm 1.915$ & 0.002 \\
Attitude & $21.68 \pm 4.539$ & $27.00 \pm$ & 0.000 \\
& & 6.151 & \\
\hline
\end{tabular}

Source: Primary Data 2020

Table 3 shows that there was an increase in the average value of respondents' knowledge before and after health education using leaflet media, from 4.08 to 5.82 . The results of the paired t-test showed a significance value of $p=0.002(\mathrm{p}<0.05)$ so it can be concluded that there are differences in the level of knowledge of respondents before and after health education regarding the importance of health checks with leaflet media.

Similarly, the attitude of the respondents who experienced an increase from 21.68 to 27.00. The results of the paired t-test showed a significance value of $p=0.000(p<0.05)$ so it can be concluded that health education using leaflet media has a significant effect on respondents' attitudes regarding the importance of health checks.

\section{DISCUSSION}

\section{Knowledge}

Health education is one of the strategies used to increase one's knowledge and abilities with the aim of changing or influencing human behavior individually, in groups or in society. Health education aims to change the behavior of individuals, groups, and the larger population, namely from behaviors that are considered detrimental to health to behaviors that provide health benefits, both now and in the future ( Simonds, 1976 in Glanz, Lewis and Rimer, 2008).

Based on the results of initial observations, it is known that out of 155 respondents, only 9 respondents $(5.8 \%)$ regularly check their blood pressure and 69 respondents $(44.5 \%)$ 
occasionally check their blood pressure. Then, there were 14 respondents $(17.9 \%)$ whose blood pressure examination results showed high blood pressure and that there were 8 respondents $(10.3 \%)$ who had been diagnosed with hypertension by a doctor.

Hypertension is often referred to as the silent killer and is the leading cause of premature death almost all over the world(1). Therefore, it is important to conduct counseling related to hypertension, including the importance of conducting regular blood pressure checks so that adults and the elderly can monitor their health conditions. The purpose of this counseling is to provide information related to hypertension risk factors, symptoms of hypertension, control and prevention of hypertension, as well as recommendations for regular health checks at least every 6 months.

The results of this study indicate that hypertension counseling using leaflet media has a positive effect on increasing the average value of respondents' knowledge, from 4.08 to 5.82. The results of the paired t-test showed a significance value of $p=0.002(p<0.05)$ so it can be concluded that there are differences in the level of knowledge of respondents before and after health education with leaflet media.

Good knowledge regarding hypertension control and prevention is a prerequisite for lifestyle modification, blood pressure control and medication adherence among adults, elderly and hypertensive patients.(10). Low knowledge about hypertension can lead to a lack of understanding about hypertension, low medication adherence so that blood pressure becomes uncontrolled(11). This study is consistent with previous findings which also showed that on average the respondents obtained a higher knowledge post-test score than the pre-test score. Health education interventions that target knowledge-raising among adults in different parts of Nigeria have been shown to reduce the prevalence of hypertension, disability, morbidity, and mortality in this sub-population.(12).

Then, intervention with leaflet media is believed to be a supporting factor in increasing knowledge related to hypertension. Media leaflets designed with contrasting color combinations, equipped with attractive pictures and clear writing are believed to increase respondents' knowledge and understanding of hypertension. Leaflet serves to strengthen the respondent's memory about the material presented. The results of this study are supported by previous studies which also showed that the leaflet provided a significant difference to the level of knowledge of hypertension and changes in blood pressure between before and after the intervention.(13). Most of the community gave a positive response to the material 
presented, enthusiastic in reading the contents of the leaflet and asking questions about hypertension and blood pressure checks.

\section{Attitude}

Attitudes are formed from three components, namely cognitive, affective, and behavioral. Attitude is defined as 'a learned tendency to think, feel and act in a certain way towards a particular object or class of objects'(Ribeaux and Poppleton, 1978 in Katz and Peberdy, 1997). Theoretically, intervention on one of the three components can affect attitudes, for example, intervention on the cognitive component by providing information that contradicts one's beliefs.(14).

The results of this study indicate that hypertension counseling using leaflet media has a positive effect on increasing the average value of respondents' attitudes, from 21.68 to 27.00. The results of the paired t-test showed a significance value of $p=0.000(p<0.05)$ so it can be concluded that there are differences in the attitudes of respondents before and after hypertension counseling with leaflet media.

The results of this study are in line with previous studies which also revealed that there was a significant increase in attitude scores regarding hypertension after giving intervention with leaflet media $(15,16)$. Based on the Health Belief Model (HBF), changes in individual perceptions and attitude adoption are influenced by four factors; perceived disease severity, perceived disease susceptibility, perceived benefits of positive attitudes and practices; as well as perceived barriers that prevent individuals from making positive changes (9).

In addition, there are studies that conclude that health education-based interventions using leaflets as conventional methods (including leaflets) are effective for reducing NCD risk factors among selected rural populations in Bangladesh. This method can be recommended as a promising strategy in various health education programs to reduce the burden of NCDs, especially in areas with inadequate resources.(17).

The level of knowledge affects respondents' attitudes about hypertension and the importance of health checks. It is known that someone who knows more about hypertension will have a better attitude towards preventing hypertension. This is in accordance with the results of previous research conducted in Iran which found a significant relationship between knowledge and attitudes about hypertension (18). 


\section{CONCLUSIONS AND SUGGESTIONS}

Based on the results of research conducted in Tanete Labba Hamlet, Baji Pa'mai Village, Cenrana District, Maros Regency, it can be concluded that health education using leaflet media has a significant effect on the level of knowledge and attitudes of respondents about hypertension and the importance of health checks. Therefore, it is important that education and extension programs are developed according to the needs of the community so that they can increase the knowledge of the general public and bring about positive changes in attitudes and practices.

\section{REFERENCES}

1. WHO. Hypertension [Internet]. Hypertension. 2021. Available from: https://www.who.int/news-room/fact-sheets/detail/hypertension

2. RISKESDAS. Riset Kesehatan Dasar 2018. Kementrian Kesehat Republik Indones. 2018;

3. Maxim LD, Niebo R, Utell MJ. Screening tests: A review with examples. Inhal Toxicol. 2014;26(13):811-828.

4. Verdecchia P, Angeli F, Cavallini C, Aita A, Turturiello D, De Fano M, et al. Sudden cardiac death in hypertensive patients. Hypertension. 2019;73(5):1071-1078.

5. Roesmono B, Hamsah, Irwan. Hubungan Perilaku Mengontrol Tekanan Darah dengan Kejadian Hipertensi. J Ilm Kesehat Pencerah. 2017;6(2):70-5.

6. Nurul Ilmi Idrus, Ansariadi JA. Determinan Pemeriksaan Rutin Tekanan Darah Pada Pasien Hipertensi Di Puskesmas Masengga Kabupaten Polewali Mandar Determinants of the Blood Pressure Check Up Routine on Hypertension Patients in Massenga Health Center Polewali Mandar District. Determ Pemeriksaan Rutin Tekanan Darah Pada Pasien Hipertens Di Puskesmas Masengga Kabupaten Polewali Mandar Determ Blood Press Check Up Routine Hypertens Patients Massenga Heal Cent Polewali Mandar Dist [Internet]. 2017;53(9):1689-99. Available from: file:///C:/Users/User/Downloads/fvm939e.pdf

7. Bryant KB, Sheppard JP, Ruiz-Negrón N, Kronish IM, Fontil V, King JB, et al. Impact of self-monitoring of blood pressure on processes of hypertension care and long-term blood pressure control. J Am Heart Assoc. 2020;9(15):e016174.

8. Sugiyono. Metode penelitian kuantitatif, kualitatif, dan R \& D. Bandung: Alfabeta. Bandung: Alfabeta; 2013.

9. Glanz K, Lewis FM, Rimer B. Health Behavior and Health Education: Theory, Research, and Practice 4th Edition. John Wiley \& Sons. 2008.

10. Chotisiri L, Yamarat K, Taneepanichskul S. Exploring knowledge, attitudes, and practices toward older adults with hypertension in primary care. J Multidiscip Healthc. 2016;9:559-564.

11. Jankowska-Polańska B, Uchmanowicz I, Dudek K, Mazur G. Relationship between patients' knowledge and medication adherence among patients with hypertension. Patient 
Prefer Adherence. 2016;10:2437-2447.

12. Ozoemena EL, Iweama CN, Agbaje OS, Umoke PCI, Ene OC, Ofili PC, et al. Effects of a health education intervention on hypertension-related knowledge, prevention and selfcare practices in Nigerian retirees: A quasi-experimental study. Arch Public Heal. 2019;77(1):1-16.

13. Ernawati I, Fandinata SS, Permatasari SN. The effect of leaflet on hypertension knowledge in hypertensive patients in community health center in Surabaya city. Open Access Maced J Med Sci. 2020;8(E):558-65.

14. Katz J, Peberdy A, editors. Promoting Health: Knowledge and Practice [Internet]. London: Macmillan Education UK; 1997. Available from: http://link.springer.com/10.1007/978-1-349-25430-9

15. Md S, George A, S. N, Gaffar PA. Development and Evaluation of Patient Information Leaflet Usefulness in Patients with Hypertension in a Tertiary Care Teaching Hospital. Manipal J Pharm Sci [Internet]. 2020;6(2):79-86. Available from: http://search.ebscohost.com/login.aspx?direct=true \&db=asn\&AN=147632193\&site=eho st-live\&authtype $=\mathrm{ip}$, shib\&user=s 1523151

16. Thomas JA, Snigdha KS, Karanath PM, Swaroop AM. Impact of Patient Counselling on Knowledge, Attitude, and Practice of Hypertensive Patients in A Tertiary Care Hospital. Int J Pharm Pharm Sci. 2017;9(9):122-9.

17. Mondal R, Sarker RC, Acharya NP, Banik PC. Effectiveness of health education-based conventional intervention method to reduce noncommunicable diseases risk factors among rural population. Cardiovasc Diagn Ther. 2019;9(1):30-4.

18. Rashidi Y, Manaflouyan H, Pournaghi Azar F, Nikniaz Z, Nikniaz L, Ghaffari S. Knowledge, attitude and practice of Iranian hypertensive patients regarding hypertension. J Cardiovasc Thorac Res. 2018;10(1):14-9. 